\title{
MICHAEL DUMMETT O FILOZOFII ANALITYCZNEJ
}

Brytyjski filozof Michael Dummett (1925-2011) należy niewątpliwie do najważniejszych filozofów analitycznych ostatnich dekad minionego wieku i początków nowego tysiąclecia. Istotnie wpłynął nie tylko na jej rozwój w zakresie filozofii języka, filozofii matematyki i metafizyki, lecz miał także znaczący udział w historycznych i metafilozoficznych dyskusjach dotyczących natury filozofii analitycznej i jej jak najtrafniejszego zdefiniowania. Wyraziste stanowisko zaprezentowane przez Dummetta w tych dyskusjach i jego krytyczna recepcja zasługują na przedstawienie i przynajmniej na kilka słów komentarza.

\section{Różnorodność i jedność filozofii analitycznej}

Programowy tekst Dummetta o tym, czy filozofia analityczna może i powinna być systematyczna, rozpoczyna się od stwierdzenia, że "termin «filozofia analityczna» denotuje nie szkołę, lecz zespół szkół, które mają wspólne pewne podstawowe presupozycje, lecz różnią się między sobą pod każdym innym możliwym względem" (Dummett [1975] 1978, s. 437). Tę wielość i jej charakter można częściowo pokazać przez zestawienie brytyjskiej filozofii analitycznej z filozofią analityczną uprawianą w Stanach Zjednoczonych. W tej drugiej, zdaniem Dummetta, kluczową postacią był Rudolf Carnap, który uprawiał filozofię w sposób naukowy i systematyczny. Pod wieloma względami podobnie postępowali jego kontynuatorzy, tacy jak Willard Van Ormand Quine i Nelson Goodman. Zwolennikiem zupełnie innej wizji filozofii był Ludwig Wittgenstein, który wywarł przemożny wpływ na brytyjską filozofię analityczną. Trwałym wątkiem jego zmieniających się poglądów filozoficznych było przekonanie, że filozofia nie jest nauka, nawet w najszerszym tego słowa znaczeniu. Nie zmierza bowiem do odkrywania i uzasadniania określonych prawd, 
lecz jedynie do usuwania nieporozumień dotyczących używanych przez nas pojęć i języka, w którym są one wyrażane.

Wszelako po odnotowaniu i opisaniu tych różnic Dummett zauważa $\mathrm{z}$ zadowoleniem, że w latach 70. minionego wieku zaczynają się one zacierać i dochodzi do zbliżania się rozmaitych tendencji w ramach filozofii analitycznej. Wymienia on trzy powody takiego stanu rzeczy. Pierwszym było coraz większe wykorzystywanie dorobku Gottloba Fregego, który okazał się myślicielem mającym kluczowy wpływ na powstanie i rozwój filozofii analitycznej. Drugim było rosnące oddziaływanie amerykańskiej filozofii analitycznej na jej brytyjską wersję, zdominowaną wcześniej przez Wittgensteina oraz oksfordzkich filozofów języka potocznego, a w szczególności Johna L. Austina i Gilberta Ryle'a. Trzeci powód był do pewnego stopnia wynikiem tych dwóch pierwszych i sprowadzał się do nadania systematycznej filozofii języka statusu centralnej dyscypliny filozoficznej, co odsunęło na dalszy plan Ryle'owskie dociekania z filozofii umysłu i drobiazgowe, lecz niesystematyczne uwagi o użyciu wyrażeń językowych, których autorami byli Austin i jego kontynuatorzy.

Wszystko to daje podstawy do tego, twierdzi z całą mocą Dummett, aby określić filozofię analityczną jako filozofię postfregańska, dla której podstawową dyscypliną jest filozofia języka. Tylko bowiem dzięki anali110 zie języka będziemy w stanie dokonać analizy myśli, a dokładniej analizy treści myśli, których nie należy utożsamiać z psychicznymi procesami myślowymi i ich mechanizmami. Sam Dummett swoją konkluzję dotyczącą natury filozofii analitycznej przedstawia następująco:

[...] Dopiero wraz z Fregem właściwym przedmiot filozofii został w końcu określony. Mianowicie ustalono, po pierwsze, że celem filozofii jest analiza struktury myśli; po drugie, że badanie myśli należy wyraźnie odróżnić od badania psychicznego procesu myślenia; a w końcu, że właściwa metoda analizowania myśli polega na analizie języka (Dummett [1975] 1978, s. 458).

Dummett był wówczas przekonany, że konkluzja ta odnosi się do całej szkoły analitycznej, aczkolwiek aby uświadomić sobie jej trafność, potrzeba było aż pół wieku od czasu śmierci Fregego.

Pod wpływem dalszego rozwoju filozofii analitycznej Dummett nieco osłabił to przekonanie, chociaż nadal opowiadał się za takim rozumieniem filozofii analitycznej, jak to właśnie zostało przedstawione. Na początku drugiego rozdziału swej szeroko dyskutowanej książki o źródłach filozofii analitycznej pisze:

[...] Filozofię analityczną w jej różnych przejawach odróżnia od innych szkół przekonanie, po pierwsze, że filozoficzne wyjaśnienie myśli można osiągnąć przez filozoficzne wyjaśnienie języka, a po drugie, że całościowe wyjaśnienie 
można osiągnąć tylko w taki sposób. Niezależnie od stopnia wzajemnych różnic, pozytywistów logicznych, Wittgensteina na wszystkich etapach rozwoju jego kariery, oksfordzką filozofię „języka potocznego" i postcarnapowską filozofię w Stanach Zjednoczonych reprezentowaną przez Quine’a i Davidsona łączyła wierność tym dwóm aksjomatom (Dummett 1993, s. 4; Dummett 2014, s. 5).

Jednakże po wskazaniu tej pary „aksjomatów” od razu zaznacza, że nie wszyscy filozofowie analityczni je akceptują. Są bowiem wśród nich tacy, którzy odwracają eksplanacyjną zależność myśli od języka i starają się wyjaśniać język, jego strukturę i funkcjonowanie za pomocą uprzednio danych różnych rodzajów myśli i ich powiązania. Jako przykład Dummett podaje filozofię przedwcześnie zmarłego oksfordzkiego myśliciela Garetha Evansa, który:

podjął się próby opracowania niezależnej od języka koncepcji tego, na czym polega myślenie o przedmiocie, na każdy z wielu różnych sposobów, a następnie starał się wyjaśnić za pomocą tych sposobów myślenia o przedmiocie różne słowne środki odnoszenia się do niego (Dummett 1993, s. 4; Dummett 2014, s. 5).

Według zaproponowanego rozumienia filozofii analitycznej Evansa nie można zatem uznać za jej przedstawiciela. Z racji jednak stylu filozofowania i nawiązywania do dorobku Fregego, Bertranda Russella i Georgéa Edwarda Moore'a trudno odmówić Evansowi przynależności do tej tradycji filozoficznej. W tym sensie, twierdzi Dummett, pozostaje on członkiem szkoły analitycznej, chociaż wprost zakwestionował jeden z jej „,aksjomatów”.

Kryjące się w tym wywodzie odróżnienie szkoły analitycznej od tradycji analitycznej zostało przez Dummetta mocniej zaakcentowane w odpowiedzi na uwagi krytyczne Charlesa Parsonsa na temat jego książki o źródłach filozofii analitycznej (Parsons 1997) ${ }^{11}$. Zauważa on tam, że można nawet zasadnie argumentować, że obecnie (tj. w końcu XX w.) nie ma już szkoły analitycznej, lecz pozostała nadal tradycja analityczna, przeciwstawiana tradycji określanej mianem filozofii kontynentalnej. Wszelako nawet jeśli ta argumentacja jest trafna, stwierdza Dummett, to nie ulega wątpliwości, że przez długi okres czasu istniała szkoła analityczna i „,warto byłoby ustalić, jaką dokładnie spuścizną szkoła ta pozostawiła tym, którzy pracują w tej tradycji i nadal uważają się za filozofów analitycznych" (Dummett 1997, s. 2).

Tak czy inaczej, sednem Dummettowskiego wyodrębnienia i określenia filozofii analitycznej jest teza, że jest to nurt myślowy, w którym dokonał się zwrot językowy lub lingwistyczny (the linguistic turn). Dummett dopatruje się początków tego zwrotu w filozofii Fregego, a dokładniej w jego dziele z 1884 r. o podstawach matematyki, w którym ten genialny

${ }^{1}$ Zmieniona i znacznie poszerzona wersja tych uwag krytycznych ukazała się jako (Parsons [2001] 2012). 
logik proponuje, aby na pytanie o sposób, w jaki dane są nam liczby, odpowiadać w drodze analizy zdań, w których występują wyrażenia liczbowe. Dla wielu historyków filozofii i badaczy dorobku Fregego ta hipoteza o początkach zwrotu lingwistycznego i filozofii analitycznej jest kontrowersyjna i jednostronna. O wiele bardziej przekonujący jest ogólny obraz filozofii analitycznej, który Dummett tak oto przybliża:

[...] We wszystkich przejawach szkoły analitycznej, począwszy od Traktatu, poprzez pozytywistów logicznych, późnego Wittgensteina, Ryle’a, Austina, Quine'a, Davidsona i Kripkego, pisma jej członków bez ustanku rozwodzą się nad językiem: nad tym, co mówimy, kiedy i z jakim skutkiem coś mówimy, co mamy na myśli, kiedy coś mówimy, i jak to należy wyjaśnić. To skupianie uwagi na języku nie zawsze się wyjaśnia lub uzasadnia. Oczywiście jeśli zmierza się do rozjaśnienia naszych pojęć, to poświęcanie nieco uwagi językowi jest nieuniknione, ponieważ posługiwanie się przez nas językiem jest najbardziej wyrazistym zastosowaniem owych pojęć; jednakże takiej mocnej koncentracji na nim nie odnajduje się w pracach filozofów spoza szkoły analitycznej (Dummett 1997, s. 3-4).

Jest to z pewnością pod wieloma względami trafny obraz filozofii analitycznej, a przynajmniej trafny w odniesieniu do niektórych jej faz rozwojowych. W mniejszym stopniu stosuje się on do kształtowania się tego nurtu filozoficznego na przełomie XIX i XX w. i rozmija się z ogólnym kierunkiem jego przemian w ostatnich kilku dekadach, a w których w filozofii analitycznej zaczęła dominować problematyka z zakresu filozofii umysłu i metafizyki. Jednakże Dummettowskie sprowadzenie tego obrazy do postaci kilku tez lub „aksjomatów”, odgrywających rolę swoistego papierka lakmusowego przy stwierdzaniu przynależności do filozofii analitycznej, spotkało się z licznymi głosami krytyki.

\section{Krytyki i repliki}

Jednym z pierwszych głosów krytycznych w tej materii był obszerny artykuł recenzyjny Barry'ego Smitha (1989), który ukazał się po publikacji niemieckiego przekładu książki Dummetta o genezie filozofii analitycznej (Dummett 1988) ${ }^{22}$. Smith zwraca m.in. uwagę, że nie tylko Evans

${ }^{2} \mathrm{Z}$ uwagi na nieco zaskakującą chronologię tej publikacji (wydanie przekładu przed ukazaniem się oryginału angielskiego), warto w tym miejscu wyjaśnić, że sednem książki Dummetta są jego wykłady wygłoszone na Uniwersytecie Bolońskim wiosną 1987 r., rok później wydrukowane we włoskim czasopiśmie „Lingua e Stile” (Dummett 1988a). Ich przekład na język niemiecki, uzupełniony obszernym wywiadem z Dummettem, ukazał się wkrótce jako odrębna pozycja książkowa (Dummett 1988b). Dopiero pięć lat później opublikowano poszerzoną przez autora angielską wersję tej książki, kilkakrotnie dodrukowywaną i wznawianą (Dummett 1993; 2014). 
jest tym filozofem, który nie akceptuje Dummetowskich "aksjomatów” przynależności do szkoły analitycznej, a jednak jak najbardziej do tradycji analitycznej należy. Jest nim także Roderick Milton Chisholm, który odegrał bardzo ważną rolę w rozwoju amerykańskiej filozofii analitycznej, a przecież zdecydowanie występował on przeciwko tezie, że myśli można adekwatnie wyjaśnić jedynie za pomocą wyjaśniania języka, chociażby wtedy, kiedy w drobiazgowej dyskusji z Wilfridem Sellarsem utrzymywał, że język i jego własności semantyczne należy opisywać i tłumaczyć przez odwołanie się do pierwotnej intencjonalności stanów umysłowych, a nie odwrotnie. Nawet jeśli pod wpływem tego rodzaju przykładów zawęzimy zakres obowiązywania Dummettowskiej charakterystyki filozofii analitycznej, to i tak będziemy musieli uznać, że jest ona uboga treściowo, gdyż nie określa bliżej, o jaką analizę myśli i języka tu chodzi. Jest wiele odmian analizy i co więcej, jest ona często uzupełniana innymi zabiegami poznawczymi i teoretycznymi. „Nawet Frege'owska idea analizy zdania zrodziła się nie z analizy języka, lecz z namysłu (można nawet powiedzieć, że z namysłu ontologicznego) nad naturą funkcji w matematyce" (Smith 1989, s. 172). Wszystkie te kłopoty Dummettowskiej charakterystyki filozofii analitycznej skłaniają do poszukiwania innego jej ujęcia. Zdaniem Smitha lepsze ujęcie powinno upatrywać jedności i wyróżnika filozofii analitycznej $\mathrm{w}$ stylu i formie, a mianowicie, mówiąc $\mathrm{w}$ dużym przybliżeniu, określać ją jako filozofię ścistą:

w tym sensie, iż dąży się w niej do jasnego i ostrożnego formułowania poglądów, co wiążę się między innymi z analizą języka (rozumianą bardzo szeroko i obejmującą wyczulenie na potencjalne niebezpieczeństwa związane z każdym użyciem języka do celów filozoficznych) (Smith 1989, s. 172-173).

We wnikliwej recenzji z angielskiego wydania książki Dummetta o źródłach filozofii analitycznej ceniony historyk filozofii analitycznej Peter Hylton ([1995] 2005) koncentruje się przede wszystkim na twierdzeniu Dummetta, że filozof analityczny musi wyraźnie oddzielać filozoficzne dociekania nad naturą myśli i ich strukturą od psychologicznego badania procesów myślowych. Myśli stanowiące przedmiot zainteresowania filozofii mają być według Dummetta obiektywnymi bytami abstrakcyjnymi, którymi posługuje się umysł ludzki w opisie i wyjaśnianiu otaczającej nas rzeczywistości. Ten obraz przedmiotu badań filozoficznych pasuje dobrze do Frege'owskiej koncepcji myśli oraz do Russellowskich sądów w sensie logicznym (propositions). Nie należy jednak zapominać, że Russellowska koncepcja sądów uległa w dwóch pierwszych dekadach XX w. daleko idącej ewolucji, w wyniku której wyeliminował on sądy jako byty abstrakcyjne i zastąpił je relacyjną teorią sądów. W myśl tej ostatniej są 
one wieloczłonową relacją umysłu ludzkiego do otaczającej go rzeczywistości. Tak ujęte sądy są zakorzenione w umyśle, lecz mają obiektywny status. Według Hyltona te różnice w statusie ontologicznym sądów lub myśli nie powinny mieć znaczenia - wbrew temu, co zdaje się twierdzić Dummett - dla tego, czy jest się filozofem analitycznym. Znaczenie powinien mieć sposób podejścia do owych myśli. $W$ tym względzie Frege i Russell zgodnie podkreślają że należy je odpowiednio analizować, tj. ustalać ich formę logiczną i umieszczać w inferencyjnej strukturze logiki. Jedności filozofii analitycznej i kryteriów przynależności do niej powinno się zatem poszukiwać w koncepcji analizy filozoficznej, która posiłkuje się, w większym lub mniejszym stopniu, narzędziami współczesnej logiki. Poszukiwanie tej jedności i tych kryteriów w filozoficznym wyjaśnianiu natury myśli za pomocą wyjaśniania funkcjonowania języka wydaje się chybione.

W obszernej monografii mającej udzielić odpowiedzi na pytanie, czym jest filozofia analityczna, Hans-Johann Glock podkreśla, że Dummettowska definicja tej filozofii była niezwykle wpływowa, chociaż oddziaływała bardziej jako „prowokacja niż inspiracja” (2008, s. 122). Rozwija on krótką definicję Dummetta do postaci pięciu tez:

(1) podstawowym celem filozofii jest analiza struktury myśli;

(2) struktura myśli to coś zupełnie innego niż struktura myślenia;

(3) jedyną właściwą metodą analizy struktury myśli jest analiza struktury języka wyrażającego myśl;

(4) konsekwencją przyjęcia takiej metody jest uznanie filozofii języka za fundament całej filozofii;

(5) centralną ideą takiego zwrotu lingwistycznego jest kontekstualizm, przyjmujący semantyczne pierwszeństwo zdań wobec ich składników.

Tezy te, twierdzi Glock, odzwierciedlają jedynie niektóre aspekty rozwoju filozofii analitycznej w XX w. Z bardzo wieloma aspektami i kierunkami tego rozwoju nie są one jednak w stanie sobie poradzić. Na przykład nie wszyscy przedstawiciele szkoły analitycznej przyjmują że podstawowym celem filozofii jest analiza struktury myśli. Glock pisze: „, „...] możemy z łatwością przystać na to, że myśl jest ważnym tematem w filozofii umysłu. Dlaczego jednak ma być ona jedynym tematem filozofii jako całości?" (2008, s. 124). Uważny czytelnik pism Dummetta mógłby odpowiedzieć, że jest to zbyt restryktywne odczytanie twierdzenia o filozofii jako analizie struktury myśli, gdyż nic nie stoi na przeszkodzie, aby poprzez tę analizę ustalać, jakie są najogólniejsze strukturalne cechy rzeczywistości, o której myślimy. Innymi słowy, według Dummetta analiza filozoficzna myśli może też być analizą przedmiotów myśli i prowadzić nas, bez 
uciekania się do szczegółowych badań empirycznych, do opracowania metafizycznej koncepcji świata, w którym żyjemy i o którym myślimy.

Replika Glocka na tę obronę metafilozoficznego stanowiska Dummetta jest następująca:

[...] Obrona ta wykorzystuje ekwiwokację między treścią naszego myślenia a jego przedmiotem. Treścią jednego z moich trwałych przekonań jest to, że Wezuwiusz jest wulkanem, zaś jego przedmiotem jest Wezuwiusz. Tylko ten przedmiot, nie zaś treść, jest częścią „świata, o którym myślimy”. Dummettowska analiza myśli nie roztrząsa głównie materialnych przedmiotów, których większość naszych myśli dotyczy, gdyż wówczas musiałaby się przerodzić w badania empiryczne. Jej przedmiotem jest raczej to, co filozofowie współcześni chętnie nazywają „treścią propozycjonalną", czyli myśl podmiotu, którą wypowiada się w zdaniu wyrażającym tę myśl (2008, s. 129).

Równie zdecydowanie Glock krytykuje pozostałe elementy Dummettowskiej definicji filozofii analitycznej, wskazując na różne niuanse ich interpretacji i przytaczając rozmaite kontrprzykłady z dziejów tradycji analitycznej. Krytyka ta utwierdza go w przekonaniu, że o wiele lepiej jest określać filozofię analityczną nie za pomocą sztywnej definicji podającej konieczne i wystarczające cechy decydujące jednoznacznie o przynależności do tego nurtu myślowego, lecz charakteryzując ją genetyczno-historycznie jako sekwencję wpływających na siebie myślicieli i prądów oraz wiążąc to wszystko cechami podobieństwa rodzinnego. Krótko mówiąc, najlepiej jest ujmować filozofię analityczną jako „tradycję zespalaną zarówno więzy wpływów, jak i przez rodzinę częściowo zachodzących na siebie cech" (Glock 2008, s. 223).

Replika Dummetta na tę krytykę Glocka była bardzo ostra. Za absurdalny uznał on zaproponowany przez Glocka sposób odróżniania treści myśli i przedmiotów stanowiących „umeblowanie” świata. Całościowa koncepcja świata nie będzie bowiem po prostu listą przedmiotów, które są w świecie. Według Dummetta „rzeczywistość należy charakteryzować przez wszystko, co jest prawdziwe i jej dotyczy; świat jest wszystkim, co zachodzi" (2011, s. 21). Innymi słowy, świat składa się nie tylko z rzeczy, lecz także z faktów, te drugie zaś są wyrażane prze prawdziwe sądy w sensie logicznym, które są przedmiotem analizy filozoficznej. Posługując się terminologią Glocka, można zatem powiedzieć, że treścią naszych prawdziwych myśli są fakty konstytuujące świat. Ogólnie rzecz biorąc, pisze Dummett w zakończeniu drugiego rozdziału swojej popularnej książki o naturze i przyszłości filozofii:

[...] Za jałowe trzeba [...] uznać pytanie, czy filozofia dotyczy rzeczywistości, czy naszych pojęć, za pośrednictwem których myślimy o rzeczywistości, czy też może narzędzi językowych, których używamy do wyrażenia tych pojęć. Inte- 
resują ją nasz pogląd na rzeczywistość, jako że zmierza do wyjaśnienia pojęć, w kategoriach których o niej myślimy, a zatem wyrażeń językowych, za pomocą których formułujemy naszą koncepcję ([2001] 2010, s. 16).

Zdaniem Dummetta twierdzenie, że zadaniem filozofii jest analiza struktury myśli nie jest bynajmniej, wbrew temu, co sugeruje Glock, konstatacją jakiegoś autonomicznego i wewnętrznego celu filozofii analitycznej, czyli swoistym metafilozoficznym wyborem. Jest raczej tak, że kiedy zaczynamy się zastanawiać nad problemami filozoficznymi, to zauważamy, że wiążą się one z zagadkami, paradoksami i nieporozumieniami, które są wynikiem chaosu pojęciowego. Aby się z nimi uporać, musimy zatem przeprowadzić analizę struktury naszych myśli.

Dummett z dezaprobatą odnosi się też do Glockowskiego ujęcia filozofii analitycznej. Jego zdaniem umiejętna charakterystyka filozofii analitycznej powinna pozwolić komuś, kto zetknął się z jakimś nieznanym dziełem filozoficznym, jednoznacznie stwierdzić, czy można go zaliczyć do tej filozofii. Tymczasem to, co zaproponował Glock w swojej książce, nie pozwala nam tego uczynić. Nie opisuje on w niej wystarczająco dobrze archetypicznych czy wzorcowych przykładów filozofii analitycznej i cech, które je łączą z innymi mniej centralnymi czy typowymi egzemplifikacjami tej filozofii.

Glock dosyć obszernie odpowiedział na tę replikę Dummetta. Jego zdaniem z tego, że całościowa koncepcja świata będzie składać się z twierdzeń o faktach, wcale nie wynika, że fakty te będą w dosłownym sensie składnikami świata, o którym myślimy. Ponadto to, co mówi Dummett, „W żaden sposób nie podważa odróżnienia między treścią przekonania - treścią tą jest fakt, o ile to przekonanie jest prawdziwe - a tym, o czym jest to przekonanie, gdzie właśnie tym czymś - jeśli pominąć szczególne przypadki - jest przedmiot, nie zaś fakt" (Glock 2011, s. 126). Nie można też bez zastrzeżeń przyjąć Dummetowskiego ujęcia natury problemów filozoficznych, niewątpliwie inspirowanego niektórymi poglądami Wittgensteina. Bardzo wielu analityków, a wręcz ich przytłaczająca większość, nie zgadza się z tym, że źródłem problemów filozoficznych są pojęciowe trudności i nieporozumienia. A jeśli tak, to twierdzenie o tym, że filozofia analizuje strukturę myśli, jest jedynie wyrazem jednej z kilku opcji metafilozoficznych w ramach filozofii analitycznej. Krytykując zaś zaproponowaną przez Glocka charakterystykę filozofii analitycznej, Dummett zdaje się zapominać, że jest ona dwuczłonowa i że o przynależności danego dzieła filozoficznego do tradycji analitycznej decyduje nie tylko jego podobieństwo do archetypicznych czy wzorcowych wytworów tej tradycji, lecz także przynależność do odpowiedniej tradycji historycznej, czego zazwyczaj nie da się ustalić w wyniku immanentnej lektury wchodzącego w grę dzieła. 


\section{Konkluzja}

Po tym przedstawieniu Dummettowskiej koncepcji filozofii analitycznej i przynajmniej niektórych wątków obszernej dyskusji, jakie ona wywołała, czas na krótkie podsumowanie. Warto tu poczynić przynajmniej dwie uwagi. Po pierwsze, chociaż Dummett prezentuje swoją koncepcję jako ktoś, kto chce zrozumieć genezę i faktyczny rozwój filozofii analitycznej oraz precyzyjnie wyznaczyć miejsce tej tradycji myślowej na mapie współczesnej filozofii, to w istocie rzeczy nie jest on typowym historykiem idei czy historykiem filozofii (od czysto faktograficznej historii filozofii sam się zresztą dystansuje), lecz w pierwszym rzędzie filozofem, który chce nam powiedzieć, czym jest filozofia, jak się ją powinno uprawiać i czym należy się inspirować. Z tego m.in. powodu jego określenie czy definicja filozofii analitycznej nie ma charakteru sprawozdawczego czy opisowego, lecz ma przede wszystkim wymiar preskryptywny, projektujący czy też normatywny. Z kolei jego krytycy poszukiwali na ogół określenia filozofii analitycznej, które byłoby historycznie trafne i opisowo adekwatne. Po drugie, niezależnie od sposobu rozumienia idei filozofii jako analizy struktury myśli poprzez analizę jej językowego wyrazu, trzeba wyraźnie zdawać sobie sprawę, że w ostatnich dekadach przedstawiciele i kontynuatorzy tradycji analitycznej programowo i ostentacyjnie odeszli od takiego rozumienia filozofii, do tego stopnia, że jednym z filarów swojego stanowiska metafilozoficznego uczynili odrzucenie zwrotu lingwistycznego, a tezę o filozofii języka jako fundamencie filozofii zastępują postulatem pierwszeństwa metafizyki (Williamson 2007; Peacocke 2019). A skoro tak, to Dummetowska koncepcja filozofii analitycznej odnosi się tylko do kilku etapów jej rozwoju, lecz rozmija się z tym, co dzieje się w niej w ostatnich latach.

\section{Bibliografia}

Dummett M. [1975] (1978), Can Analytical Philosophy be Systematic, and Ought it to Be?, [w:] idem, Truth and Other Enigmas, Duckworth, London, s. 437-458.

Dummett M. (1988a), The Origins of Analytical Philosophy, cz. 1-2, „Lingua e Stile” 23, s. $3-49,171-210$.

Dummett M. (1988b), Ursprünge der analytischen Philosophie, Suhrkamp, Frankfurt am Main. Dummett M. (1993), Origins of Analytical Philosophy, Duckworth, London.

Dummett M. (1997), Response to Charles Parsons, maszynopis przygotowany na sympozjum o książce Origins of Analytical Philosophy w ramach dorocznego zjazdu centralnego oddziału The American Philosophical Association, Pittsburgh, PA, 23-26 kwietnia 1997.

Dummett M. [2001] (2010), Natura i przyszłość filozofii, Wydawnictwo IFiS PAN, Warszawa. Dummett M. (2011), On Analytical Philosophy, „,Teorema. Revista Internacional de Filosofía” 30(1), s. 19-21. 
Dummett M. (2014), Origins of Analytical Philosophy, Bloomsbury, London.

Glock H.-J. (2008), What is Analytic Philosophy?, Cambridge University Press, Cambridge.

Glock H.-J. (2011), Replies to My Commentators, „Teorema. Revista Internacional de Filosofía" 30(1), s. 115-144.

Hylton P. [1995] (2005), Review of Dummett's "Origins of Analytical Philosophy", [w:] idem, Propositions, Functions, and Analysis: Selected Essays on Russell's Philosophy, Clarendon Press, Oxford, s. 115-121.

Parsons C. (1997), Dummett's "Origins of Analytical Philosophy”, maszynopis przygotowany na sympozjum o książce Origins of Analytical Philosophy w ramach dorocznego zjazdu centralnego oddziału The American Philosophical Association, Pisttburgh, PA, 23-26 kwietnia 1997.

Parsons C. [2001] (2012), Husserl and the Linguistic Turn, [w:] idem, From Kant to Husserl: Selected Essays, Harvard University Press, Cambridge, s. 190-214.

Peacocke C. (2019), The Primacy of Metaphysics, Oxford University Press, Oxford,

Smith B. (1989), On the Origins of Analytic Philosophy, "Grazer Philosophische Studien” 35, s. 153-173.

Williamson T. (2007), The Philosophy of Philosophy, Blackwell Publishing, Malden.

\section{Streszczenie: Michael Dummett o filozofii analitycznej}

Brytyjski myśliciel Michael Dummett (1925-2011) nie tylko istotnie wpłynął na rozwój filozofii analitycznej w zakresie filozofii języka, filozofii matematyki i metafizyki, lecz także miał znaczący udział w historycznych i metafilozoficznych dyskusjach dotyczących natury tej filozofii i jej właściwego definiowania. Zaproponował on rozumienie filozofii analitycznej jako filozofii, która analizuje strukturę myśli poprzez analizę struktury języka. Jest to zatem filozofia, której sednem jest zwrot lingwistyczny. Liczni krytycy tej propozycji (między innymi Barry Smith, Peter Hylton i Hans-Johann Glock) zwracali uwagę, że ujmuje on tylko niektóre aspekty tej zróżnicowanej tradycji filozoficznej i że nie jest ona historycznie adekwatna.

Słowa kluczowe: Michael Dummett, szkoła analityczna, tradycja analityczna, zwrot lingwistyczny, Barry Smith, Peter Hylton, Hans-Johann Glock, przedmiot filozofii, problem filozoficzny

\section{Summary: Michael Dummett on Analytical Philosophy}

The British philosopher Michael Dummett (1925-2011) not only had a massive influence on the development of analytical philosophy within philosophy of language, philosophy of mathematics, and metaphysics, but also contributed significantly to historical and metaphilosphical debates about the nature of this philosophical movement and its proper account. He proposed to define analytical philosophy as philosophy whose aim is the analysis of the structure of thought by way of the analysis of language. Hence, it is philosophy the gist of which is the linguistic turn. 
A number of critics of this proposal (including Barry Smith, Peter Hylton, and Hans-Johann Glock) emphasised that Dummett's proposal captures merely some features of this diversified and multifaceted philosophical tradition, and is far from being historically adequate.

Keywords: Michael Dummett, analytical school, analytical tradition, linguistic turn, Barry Smith, Peter Hylton, Hans-Johann Glock, subject matter of philosophy, philosophical problem 